\title{
Syntheses, Characterization, and X-ray Crystal Structure of Heteronuclear Zn/Na Assembled with Salen-type Schiff Base
}

\author{
Pokpa Haba $^{1}$, Mouhamadou Moustapha Sow ${ }^{2}$, Mamour Sarr ${ }^{1}$, Ibrahima Elhadji Thiam ${ }^{1}$, \\ Mahy Diaw ${ }^{2}$, Pascal Retailleau ${ }^{3}$, Mohamed Lamine Gaye ${ }^{1, *}$ \\ ${ }^{1}$ Department of Chemistry, University Cheikh Anta Diop, Dakar, Senegal \\ ${ }^{2}$ Department of Chemistry, University Alioune Diop, Bambey, Senegal \\ ${ }^{3}$ Natural Substances Laboratory, University Paris-Sud, Gif-sur-Yvette, France
}

Email address:

mohamedl.gaye@ucad.edu.sn (M. L. Gaye)

${ }^{*}$ Corresponding author

\section{To cite this article:}

Pokpa Haba, Mouhamadou Moustapha Sow, Mamour Sarr, Ibrahima Elhadji Thiam, Mahy Diaw, Pascal Retailleau, Mohamed Lamine Gaye. Syntheses, Characterization, and X-ray Crystal Structure of Heteronuclear Zn/Na Assembled with Salen-type Schiff Base. Science Journal of Chemistry. Vol. 8, No. 5, 2020, pp. 113-118. doi: 10.11648/j.sjc.20200805.13

Received: September 9, 2020; Accepted: September 23, 2020; Published: September 29, 2020

\begin{abstract}
Herein we reported the crystal structure of a dinuclear complex $\left.\left[\left\{\mathrm{Zn}^{\mathrm{II}} \mathrm{Na}{ }^{\mathrm{I}}(\mathrm{L})(\mathrm{EtOH})\left(\mathrm{NO}_{3}\right)\right]\right\}\right](2)$ obtained by reaction with the metalloligand $[\mathrm{Zn}(\mathrm{L})] \cdot\left(\mathrm{H}_{2} \mathrm{O}\right)(1)$ and sodium nitrate. The metalloligand (1) and the dinuclear (2) complexes are characterized by IR and physical measurement. Spectroscopic evidence indicated that the Schiff base $\mathrm{H}_{2} \mathrm{~L}$ behave an $\mathrm{N}_{2} \mathrm{O}_{2} \mathrm{O}_{2}$ ' coordination tetradentate ligand. Suitable crystals of the compound 2 were grown by slow evaporation of ethanol solution for two weeks. The structure of 2 was elucidated by X-ray diffraction analysis. The compound crystallizes in the monoclinic crystal system with a space group of $P 2_{1} / c$. The asymmetric unit of the compound contains one dideprotonated ligand molecule, on tetracoordinated zinc (II) ion, one heptacoordinated sodium(I) ion, one bidentate nitrate group and one coordinated ethanol molecule resulting in a structure formulated as $\left[\mathrm{Zn}(\mu-L) \mathrm{Na}\left(\mathrm{NO}_{3}\right)(\mathrm{EtOH})\right]$. In the structure the $\mathrm{Zn}^{\mathrm{II}}$ ion is tetracoordinated and the environment around the zinc (II) is best described as a planar square geometry. The $\mathrm{Na}^{\mathrm{I}}$ ion is sevencoordinated in a severely distorted bipyramid pentagon environment. The interplanar angles between the two phenyl rings with a methoxy substituent is $4.208(4)^{\circ}$, while the dihedral angle values of these groups with the phenyl carrying amino groups are respectively $7.499(5)^{\circ}$ and $11.594(5)^{\circ}$. The $\mathrm{Zn}-\mathrm{Na}$ distance is 3.4244 (9) $\AA$. In the crystal structure numerous intramolecular and intermolecular hydrogen bonds link the molecules in a three-dimensional network.
\end{abstract}

Keywords: Zinc, Metalloligand, o-vanillin, 1, 2-diaminobenzene

\section{Introduction}

Chemists are increasingly interested in the design and synthesis of heteropolynuclear complexes of $\mathrm{d}$ and $s$-block elements owing to original structures with interesting properties in various fields such as magnetism $[1,2]$, catalysis [3, 4] and luminescence [5]. The major procedure used for synthesizing these kings of complexes consist to prepare a metal-ligand with Schiff base containing two inners of different sizes $[6,7]$. In the metal-ligand, the $3 d$ element occupy the inner with the smaller size $[8,9]$. The reactions of these metal-ligand complexes with metallic centers of different natures can lead polynuclear compounds with very varied structures. Organic ligands capable of maintaining the $\mathrm{M}^{\mathrm{n}+}(\mathrm{n}=2$ or 3$)$ ion from $d$-block and the $\mathrm{M}^{\mathrm{n}^{\prime+}+}$ ion $\left(\mathrm{n}^{\prime}=1\right.$ or 2) from s-block by bridging, are widely used to establish M(di- $\mu$-phenoxo $)_{2}-\mathrm{M}^{\prime}$ bridges in order to improve exchanges between metal centers [10-12]. The coordination chemistry of s-block elements has recently developed due to the presence of alkaline elements in biomolecular recognition $[13,14]$. One of the most studied ions is $\mathrm{Na}+$ and some structures containing this element of the bock $\mathrm{s}$ and an element of the block $d$ show that the element $\mathrm{s}$ is located in 
the larger site while the transition ion is in the smaller site [6, 7, 15, 16]. The Schiff base bis (2-hydroxy-3methoxybenzylidene)-1, 2-diaminobenzene, is widely used for synthetizing several $3 \mathrm{~d} / \mathrm{Na}$ heteronuclear complexes whose structures show that the element of s-block is still located in the larger open site, while the d-block element is situated in the smaller closed site $[16,17]$. Organic molecules with phenolic oxygen atoms are perspective that the work we report focused on the use of the $\mathrm{H}_{2} \mathrm{~L}$ Schiff base $(\mathrm{H} 2 \mathrm{~L}=N$,
$N$-Phenylene-bis-(3-methoxysalicylideneimine)) which has two inners capable to encapsulate two ions of different natures. It is in this context that we report the synthesis of a complex $\mathrm{Zn}^{2+} / \mathrm{Na}^{+}$formulated as follows $[\mathrm{Zn}(\mu$ $\left.L) \mathrm{Na}\left(\mathrm{NO}_{3}\right)(\mathrm{EtOH})\right]$. The compound is obtained by initially isolating the mononuclear zinc (II) complex before reacting the latter with sodium thiocyanate to obtain a heterotrinuclear complex (Figure 1). The crystal structure and the physicochemical are reported herein.

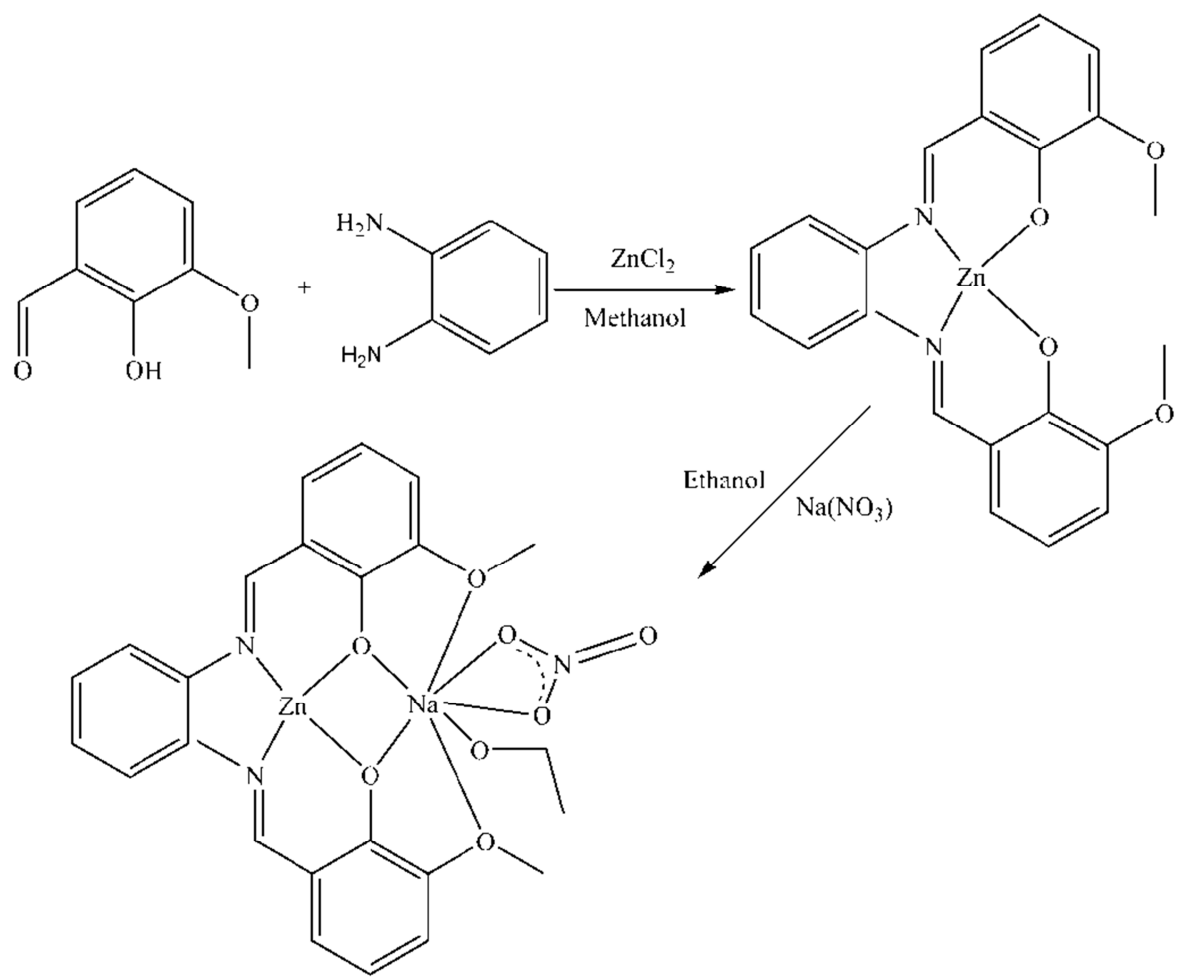

Figure 1. Chemical diagrams for $[\mathrm{Zn}(\mathrm{L})] \cdot\left(\mathrm{H}_{2} \mathrm{O}\right)(1)$ and $\left.\left[\left\{\mathrm{Zn}^{I I} \mathrm{Na}(\mathrm{L})(\mathrm{EtOH})\left(\mathrm{NO}_{3}\right)\right]\right\}\right]$ (2).

\section{Materials and Methods}

\subsection{General Information}

o-vanillin and 1, 3-diaminobenzene, zinc chloride tetrahydrate, and sodium nitrate were purchased from SigmaAldrich and used as received without further purification. All solvents used were of reagent grade. The ligand $\left(\mathrm{H}_{2} \mathrm{~L}\right)$ was synthesized following the reported procedure [18]. Elemental analyses of $\mathrm{C}, \mathrm{H}$ and $\mathrm{N}$ were recorded on a VxRio EL Instrument. Infrared spectra were obtained on an FTIR Spectrum Two of Perkin Elmer spectrometer in the 4000-400 $\mathrm{cm}^{-1}$ region. The molar conductance of $1 \times 10^{-3} \mathrm{M}$ in DMSO solutions of the metal complexes was measured at $25^{\circ} \mathrm{C}$ using a WTW LF-330 conductivity meter with a WTW conductivity cell.

\subsection{Synthesis and Characterization of (1) and (2)}

In a round bottomed flask, the ligand $\left(\mathrm{H}_{2} L\right)(1 \mathrm{mmol}$, $0.374 \mathrm{~g}$ ) was dissolved in $5 \mathrm{~mL}$ of acetonitrile. A solution of $\mathrm{ZnCl}_{2}$ (1 mmol, $0.1363 \mathrm{~g}$ ) in $5 \mathrm{~mL}$ of methanol was added. After two hours under reflux, the yellowish precipitate was recovered by filtration, washed with ether $(2 \times 10 \mathrm{~mL})$ and dried in air. The compound was formulated as $[\mathrm{Zn}(L)] .\left(\mathrm{H}_{2} \mathrm{O}\right)$. Yield: $85 \%$. Elemental Anal. Found (Calcd.) (\%): C, 57.72 (57.75); H, 4.40 (4.36); N, 6.12 (6.10). IR (, $\left.\mathrm{cm}^{-1}\right)$ : [v(O-H) $\left.3340, \delta\left(\mathrm{OH}_{2}\right) 851\right] ; 1625 v(\mathrm{C}=\mathrm{N}), 1592 ; \mathrm{v}(\mathrm{C}-\mathrm{OPh}), 1233$; $v(\mathrm{C}-\mathrm{OMe}), 1201 . \Lambda\left(\mathrm{S} . \mathrm{cm}^{2} \cdot \mathrm{mol}^{-1}\right): 10$.

To a solution of $[\mathrm{Zn}(L)] \cdot \mathrm{H}_{2} \mathrm{O}(1)(1 \mathrm{mmol}, 0.4578 \mathrm{~g})$ in $5 \mathrm{~mL}$ of DMF was added a solution of $\mathrm{NaNO}_{3}(3 \mathrm{mmol}, 0.255 \mathrm{~g})$ in 5 $\mathrm{mL}$ of ethanol. The mixture was refluxed for two hours. On cooling yellow solution was filtered. The filtrate was left for slow evaporation. On standing for two weeks, yellow crystals of (2) suitable for X-ray diffraction were isolated. Yield: $78.9 \%$. Elemental Anal. Found (Calcd.) (\%): C, 50.50 (50.48); H, 4.24 (4.22); N, 7.36 (7.38). IR ( $\left.v, \mathrm{~cm}^{-1}\right): 3429,3190,3090,1617$ $v(\mathrm{C}=\mathrm{N}) ; 1586 ; 1533 ; 1485 ; 1460 ; 1241 v(\mathrm{C}-\mathrm{OPh}) ; \mathrm{v}(\mathrm{C}-\mathrm{OMe})$ 1197; [1488 $v_{1}\left(\mathrm{NO}_{3}\right) ; 1313 v_{5}\left(\mathrm{NO}_{3}{ }^{-}\right) ; 1041 v_{2}\left(\mathrm{NO}_{3}{ }^{-}\right) ; \Delta v 175 \mathrm{~cm}^{-}$ $\left.{ }^{1}\right]$. Conductance $\Lambda\left(\mathrm{S}^{\mathrm{cm}}{ }^{2} \cdot \mathrm{mol}^{-1}\right): 5$.

\subsection{Crystal Structure Determination}

Crystals suitable for single-crystal X-ray diffraction, of the reported compounds, were grown by slow evaporation of $\mathrm{MeOH}$ solution of the complexes. Details of the crystal 
structure solution and refinement are given in Table 1. Diffraction data were collected using an ENRAF NONIUS Kappa CCD diffractometer with graphite monochromatized MoK $\alpha$ radiation $(\lambda=0.71073 \AA)$. All data were corrected for Lorentz and polarization effects. No absorption correction was applied. Complex scattering factors were taken from the program package SHELXTL [19]. The structures were solved by direct methods, which revealed the position of all non-hydrogen atoms. All the structures were refined on $F^{2}$ by a full-matrix least-squares procedure using anisotropic displacement parameters for all non-hydrogen atoms [20]. The hydrogen atoms of water molecules and $\mathrm{NH}$ groups were located in the Fourier difference maps and refined. Others $\mathrm{H}$ atoms ( $\mathrm{CH}$ and $\mathrm{CH}_{3}$ groups) were geometrically optimized and refined as riding model by AFIX instructions. Molecular graphics were generated using ORTEP-3 [21]

\section{Results and Discussion}

\subsection{General Study}

The ligand $\quad \mathrm{H}_{2} L \quad$ 2-(-(2-(-2-hydroxy-3methoxybenzylideneamino) phenylimino) methyl)-6methoxyphenol was prepared by mixing under reflux ovanillin and 1, 2-diamino benzene in molar ratio 2:1 in ethanol, following a reported method [18]. The $\mathrm{H}_{2} L$ react with $\mathrm{ZnCl}_{2}$ in methanol to yield $[\mathrm{Zn}(L)] \cdot \mathrm{H}_{2} \mathrm{O}$ (1). This metalloligand react with sodium nitrate in molar ratio $1: 3$ and the complex formulated as $\left[\left\{\mathrm{Zn}^{\mathrm{II}} \mathrm{Na}^{\mathrm{I}}(L)\left(\mathrm{NO}_{3}\right)\right\}\right]$ (2) was afforded after slow evaporation of the filtrate. The IR spectrum of the metalloligand (1) shows an absorption band at $1625 \mathrm{~cm}^{-1}\left(1632 \mathrm{~cm}^{-1}\right.$ for the free $\left.\mathrm{H}_{2} \mathrm{~L}\right)$ which is indicative of a coordinated azomethine $(\mathrm{C}=\mathrm{N})$. Additional band $\mathrm{v}(\mathrm{C}$ $\mathrm{OPh})$ is pointed at $1233 \mathrm{~cm}^{-1}$ correspond to the deprotonated phenoxy group. The corresponding band in the free ligand appears at $1254 \mathrm{~cm}^{-1}$ band. For the complex (2) the $v(C=N)$ band is pointed at $1617 \mathrm{~cm}^{-1}$ and $\mathrm{v}(\mathrm{C}-\mathrm{OPh})$ is shifted to high frequency and pointed at $1241 \mathrm{~cm}^{-1}$. The bands at $1488\left(v_{1}\right)$, $1313\left(v_{5}\right), 1041\left(v_{2}\right)$ and $v_{1}-v_{5}=175 \mathrm{~cm}^{-1}$ are indicative of the presence of a bidentate chelating nitrate group. The molar conductance $\Lambda$ measured in DMF solution are 5 and $7 \mathrm{~S} \mathrm{~cm}^{2}$ $\mathrm{mol}^{-1}$ respectively for (1) and (2) which are indicative of a neutral electrolytes [22].

\subsection{Crystal Structure}

A novel hetero neutral dinuclear $\left(\mathrm{Zn}^{\mathrm{II}} \mathrm{Na}^{\mathrm{I}}\right)$ compound has been obtained by step-by-step method and its structure is depicted. The compound crystallizes in the monoclinic crystal system with a space group of $P 2_{l} / c$. The asymmetric unit of the structure of $\left[\mathrm{Zn}(\mu-L) \mathrm{Na}\left(\mathrm{NO}_{3}\right)(\mathrm{EtOH})\right]$ contains one dideprotonated $L^{2-}$ ligand molecule $\mathrm{H}_{2} L=N, N^{\prime}$ Phenylene-bis-(3-methoxysalicylideneimine)), one $\mathrm{Zn}^{\mathrm{II}}$ cation, one $\mathrm{Na}^{\mathrm{I}}$ cation, one bidentate nitrate anion and one coordinated ethanol molecule. The molecular structure of the title compound is shown in Figure 2, while selected bond lengths and angles of the coordination environment of the metal centers are listed in Table 2. In the structure of the dinuclear complex, the $\mathrm{Zn}$ atom and the $\mathrm{Na}$ atom are bridged by two phenoxo oxygen atoms. The four-coordinated $\mathrm{Zn}^{\text {II }}$ ion, which occupy the smaller inner of the ligand, is coordinated in a planar square geometry with the basal plane formed by two nitrogen atoms and two phenoxo oxygen atoms. The cissoid angles around the zinc atom which are in the range $\left[84.77(7)^{\circ}-95.06(6)^{\circ}\right]$, significantly deviates from the ideal values of $90^{\circ}$. The diagonal basal angles are respectively $\mathrm{N} 1-\mathrm{Zn} 1-\mathrm{O} 2=177.91(7)^{\circ}$ and $\mathrm{N} 2-\mathrm{Zn} 1-\mathrm{O} 1=$ $178.73(6)^{\circ}$ slightly deviates from the ideal values of $180^{\circ}$. These values are comparable to those reported for similar complexes [23]. The zinc atom lies nearly in the plane defined by the $\mathrm{N}_{2} \mathrm{O}_{2}$ site, the out-of-plane distance being 0.0211 (1) $\AA$. The two $\mathrm{Zn}-\mathrm{N}$ bond distance values are 1.9404 (15) $\AA[\mathrm{Zn} 1-\mathrm{N} 1]$ and 1.9278 (16) $\AA$ [Zn1-N2], and the Zn-O bond distances which lie in the range of 1.8874 (14) $\AA_{-}$ 1.8937 (13) $\AA$, are in accordance with the reported values for the complex $\left[\mathrm{Zn}(\mu-L) \mathrm{La}\left(\mathrm{NO}_{3}\right)_{3}\left(\mathrm{H}_{2} \mathrm{O}\right)_{2}\right]$ [24]. The $\mathrm{Na}^{\mathrm{I}}$ ion, which occupy the larger open site $\mathrm{O}_{2} \mathrm{O}_{2}$ of the ligand, is ligated to two phenoxo oxygen atoms and two methoxy oxygen atoms of the ligand, two oxygen atoms of one bidentate nitrate group and one oxygen atom from a molecule of ethanol. The $\mathrm{Na}-\mathrm{O}_{\text {phenoxo }}$ bond distances are in the range of 2.3953 (16) $\AA-2.4253$ (16) $\AA$ (Figure 2, Table 2) and are shorter than the $\mathrm{Na}-\mathrm{O}_{\text {methoxy }} 2.6085$ (18) $\AA-2.6350$ (18) $\AA$. The distances are comparable to those found in the similar complex $\left[\mathrm{Cu}(\mu-L) \mathrm{Na}\left(\mathrm{ClO}_{4}\right)(\mathrm{DMF})\right]$ [12]. The distances of the $\mathrm{Na}^{\mathrm{I}}$ cation to the two oxygen atoms from the bidentate nitrate group [Na1-O5 2.490 (2) $\AA$; Na1-O6 2.514 (2) $\AA$ ] and the oxygen atom of the ethanol molecule [Na1-O8 2.364 (2) $\AA]$ are in accordance with those found for the complex $\left.\left[\left\{\mathrm{Fe}^{\mathrm{II}} \mathrm{Na}^{\mathrm{I}}(L)(\mathrm{EtOH})\left(\mathrm{HN}(\mathrm{CN})_{2}\right)\right\}(\mu-\mathrm{O})\left\{\mathrm{Fe}^{\mathrm{III}} \mathrm{Na}^{\mathrm{I}}(L)\left(\mathrm{NO}_{3}\right)\right]\right\}\right]_{\mathrm{n}}$ [25]. The sodium cation is situated in the planar cavity defined by the two phenoxo oxygen atoms and the two methoxy oxygen atoms with maximum displacement of 0.131 (1) $\AA$. The interplanar angles between the two phenyl groups with a methoxy substituent is $4.208(4)^{\circ}$, while the dihedral angle values of these groups with the phenyl carrying amino groups are respectively $7.499(5)^{\circ}$ and 11.594 $(5)^{\circ}$. The $\mathrm{Zn}-\mathrm{Na}$ distance is 3.4244 (9) $\AA$. The positive charge of the $\mathrm{Zn}(\mathrm{II})$ and $\mathrm{Na}(\mathrm{I})$ ions are balanced by the ligand $L^{2-}$ and the nitrate anion.

The environment around the 7-fold sodium atom is best described as a severely distorted bipyramid pentagon (Figure 3). The basal angles are in the range [60.57 (5)-96.31 (7)]. These values deviate from the value of the ideal angle for a regular pentagon $\left(72^{\circ}\right)$ and the sum of the equatorial angles around the sodium atom is $365.53^{\circ}$. The apical position for the pentagon pyramid around $\mathrm{Na}$ is occupied by $\mathrm{O} 5$ and $\mathrm{O} 8$ with the angle value of $136.37(7)^{\circ}$.

The dinuclear units are connected by hydrogen bonds of type EtO- $\mathrm{H} \cdots \mathrm{O}-\mathrm{NO}_{2}$ and, weak intermolecular hydrogen bonds of type $\mathrm{C}-\mathrm{H} \cdots \mathrm{O}-\mathrm{NO}_{2} \quad\left(\mathrm{C} 13-\mathrm{H} \cdots \mathrm{O} 7^{\mathrm{ii}}\right.$ and $\mathrm{C} 15-$ $\mathrm{H} \cdots \mathrm{O} 5^{\mathrm{ii}}$ ) (Figure 4, Table 3 ). The combined hydrogen bonds links give rise to a three-dimensional network architecture. It should be noted that the methoxy and phenoxo oxygen atoms are by no means engaged in any interaction in the structure. 
A survey of the Cambridge Structural Database (CSD) (Version 5.39, last update November 2017; Groom et al., 2016) [26] shows that dinuclear complexes of the ligand bis(2-hydroxy-3-methoxybenzylidene)-1, 2-diaminobenzene where the smaller $\mathrm{N}_{2} \mathrm{O}_{2}$ cage is occupied by a $3 \mathrm{~d}$ metal and the larger, open $\mathrm{O}_{2} \mathrm{O}_{2}$ cage is occupied by one s-block metal are well documented. Complexes formed by transition metal and s-block atom, with the above organic ligand in which the d-block metal atom is situated in the smaller $\mathrm{N}_{2} \mathrm{O}_{2}$ cage and the s-block metal atom is situated in the larger $\mathrm{O}_{2} \mathrm{O}_{2}$ cage have been reported: twelve entries corresponding to $\mathrm{d}-\mathrm{s}$ complexes [1, 10, 11, 16, 27-29] were found in the CSD. One trinuclear $\mathrm{Ni}-\mathrm{K}-\mathrm{Ni}$ complex has been reported recently [30].

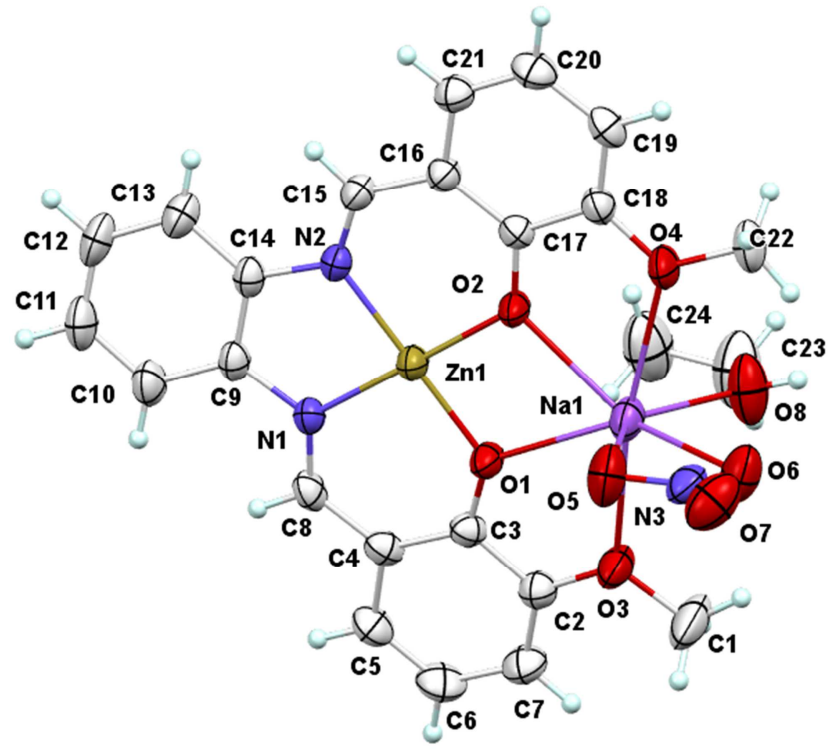

Figure 2. Crystal structure of the tetranuclear complex (2).

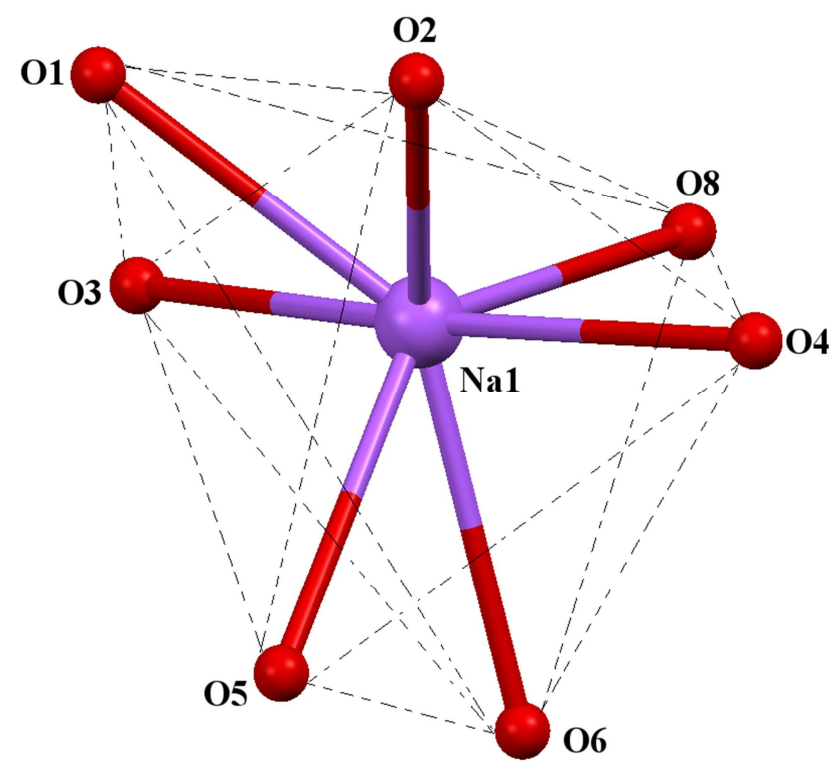

Figure 3. Plot showing the coordination sphere of the two sodium ions in the crystal.

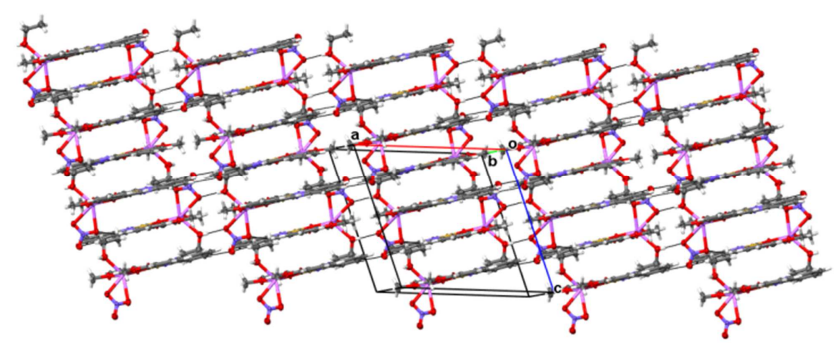

Figure 4. The packing of the complex in the crystal structure.

Table 1. Crystal data, X-ray data collection, data reduction and structure refinement for 2 .

\begin{tabular}{|c|c|}
\hline \multicolumn{2}{|l|}{ Crystal data } \\
\hline Chemical formula & $\mathrm{C}_{24} \mathrm{H}_{24} \mathrm{~N}_{3} \mathrm{NaO}_{8} \mathrm{Zn}$ \\
\hline$M \mathrm{r}$ & 570.86 \\
\hline Crystal system, space group & Monoclinic, $\mathrm{P} 2{ }_{1} / \mathrm{c}$ \\
\hline Temperature $(\mathrm{K})$ & 292 \\
\hline$a, b, c(\AA)$ & $13.7247(5), 13.7805(4), 13.4006(6)$ \\
\hline$\beta\left(\left(^{\circ}\right)\right.$ & $110.209(5)$ \\
\hline$V\left(\AA^{3}\right)$ & $2378.47(17)$ \\
\hline$Z$ & 4 \\
\hline Calculated density $\left(\mathrm{g} . \mathrm{cm}^{-3}\right)$ & 1.5941 \\
\hline $\mathrm{F}(000)$ & 1178 \\
\hline Radiation type & $\lambda=0.71073 \AA$ \\
\hline$\mu\left(\mathrm{mm}^{-1}\right)$ & 1.11 \\
\hline Crystal size (mm) & $0.03 \times 0.02 \times 0.01$ \\
\hline \multicolumn{2}{|l|}{ Data collection } \\
\hline Diffractometer & XtaLAB AFC12 (RCD3): Kappa single \\
\hline Absorption correction & Multi-scan \\
\hline$T_{\min }, T_{\max }$ & $0.233,1.000$ \\
\hline \multicolumn{2}{|l|}{ Limiting indices } \\
\hline $\mathrm{h}$ & $-18 \rightarrow 17$ \\
\hline $\mathrm{k}$ & $0 \rightarrow 18$ \\
\hline 1 & $0 \rightarrow 18$ \\
\hline $\begin{array}{l}\text { No. of measured, independent } \\
\text { and observed }[I \geq 2 \sigma(I)] \\
\text { reflections }\end{array}$ & $57221,13219,11414$ \\
\hline$R_{\text {int }}$ & 0.049 \\
\hline \multicolumn{2}{|l|}{ Refinement } \\
\hline$R\left[F^{2}>2 \sigma\left(F^{2}\right)\right], w R\left(F^{2}\right), S$ & $0.039,0.107,1.05$ \\
\hline No. of reflections & 5628 \\
\hline No. of parameters/restraints & $340 / 1$ \\
\hline $\mathrm{H}$-atom treatment & $\begin{array}{l}\mathrm{H} \text { atoms treated by a mixture of } \\
\text { independent and constrained refinement }\end{array}$ \\
\hline$\Delta \rho \max , \Delta \rho \min \left(\mathrm{e} \AA^{-3}\right)$ & $0.38 \&-0.56$ \\
\hline
\end{tabular}

Table 1. Selected bond lengths [A] and angles (') for the complex 2.

\begin{tabular}{llll}
\hline Bond & Bond length $[\AA]]$ & Bond & Bond angles $\left(^{\circ}\right)$ \\
\hline $\mathrm{Na} 1-\mathrm{O} 8$ & $2.364(2)$ & $\mathrm{O} 2-\mathrm{Na} 1-\mathrm{O} 1$ & $64.39(5)$ \\
$\mathrm{Na} 1-\mathrm{O} 2$ & $2.3953(16)$ & $\mathrm{O} 2-\mathrm{Na} 1-\mathrm{O} 4$ & $61.35(5)$ \\
$\mathrm{Na} 1-\mathrm{O} 1$ & $2.4253(16)$ & $\mathrm{O} 6-\mathrm{Na} 1-\mathrm{O} 4$ & $82.68(7)$ \\
$\mathrm{Na} 1-\mathrm{O} 5$ & $2.490(2)$ & $\mathrm{O} 1-\mathrm{Na} 1-\mathrm{O} 3$ & $60.57(5)$ \\
$\mathrm{Na} 1-\mathrm{O} 6$ & $2.514(2)$ & $\mathrm{O} 6-\mathrm{Na} 1-\mathrm{O} 3$ & $96.31(7)$ \\
$\mathrm{Na} 1-\mathrm{O} 4$ & $2.6085(18)$ & $\mathrm{O} 1-\mathrm{Zn} 1-\mathrm{O} 2$ & $85.58(6)$ \\
$\mathrm{Na} 1-\mathrm{O} 3$ & $2.6350(18)$ & $\mathrm{O} 1-\mathrm{Zn} 1-\mathrm{N} 2$ & $178.73(6)$ \\
$\mathrm{Zn} 1-\mathrm{O} 1$ & $1.8875(14)$ & $\mathrm{O} 2-\mathrm{Zn} 1-\mathrm{N} 2$ & $95.06(6)$ \\
$\mathrm{Zn} 1-\mathrm{O} 2$ & $1.8937(13)$ & $\mathrm{O} 1-\mathrm{Zn} 1-\mathrm{N} 1$ & $94.55(7)$ \\
$\mathrm{Zn} 1-\mathrm{N} 2$ & $1.9278(16)$ & $\mathrm{O} 2-\mathrm{Zn} 1-\mathrm{N} 1$ & $177.91(7)$ \\
$\mathrm{Zn} 1-\mathrm{N} 1$ & $1.9404(15)$ & $\mathrm{N} 1-\mathrm{Zn} 1-\mathrm{N} 2$ & $84.77(7)$ \\
$\mathrm{Na} 1-\mathrm{Zn} 1$ & $3.4244(9)$ & $\mathrm{Zn} 1-\mathrm{O} 1-\mathrm{Na} 1$ & $104.43(6)$ \\
& & $\mathrm{Zn} 1-\mathrm{O} 2-\mathrm{Na} 1$ & $105.36(6)$ \\
\hline
\end{tabular}


Table 3. Hydrogen-bond geometry $\left(\AA,{ }^{\circ}\right)$.

\begin{tabular}{lllll}
\hline $\boldsymbol{D}-\mathbf{H} \cdots \boldsymbol{A}$ & $\boldsymbol{D}-\mathbf{H}$ & $\mathbf{H} \cdots \boldsymbol{A}$ & $\boldsymbol{D} \cdots \boldsymbol{A}$ & $\boldsymbol{D}-\mathbf{H} \cdots \boldsymbol{A}$ \\
\hline O8-H8 $\cdots \mathrm{O}^{\mathrm{i}}$ & $0.798(19)$ & $2.116(19)$ & $2.912(3)$ & $174(4)$ \\
$\mathrm{C} 15-\mathrm{H} 15 \cdots \mathrm{O}^{\mathrm{ii}}$ & 0.93 & 2.51 & $3.392(3)$ & 158.7 \\
$\mathrm{C} 13-\mathrm{H} 13 \cdots \mathrm{O}^{\mathrm{ii}}$ & 0.93 & 2.60 & $3.406(3)$ & 145.0 \\
\hline
\end{tabular}

Symmetry codes: (i) $-\mathrm{x}+2,-\mathrm{y}+1,-\mathrm{z}+1$; (ii) $-\mathrm{x}+1,-\mathrm{y}+1,-\mathrm{z}+1$.

\section{Conclusion}

In summary, we have successfully synthesized and studied the hetero dinuclear complex containing one zinc (II) and one natrium (I) ions. A suitable crystal of the complex was obtained by slow evaporation of ethanol solution of the compound for two weeks. Infrared spectra of the compound and the metalloligand were discussed in this paper. Crystal data, X-ray data collection, data reduction and structure refinement of complex 2 are studied. The heteronuclear complex crystallizes in the monoclinic system with a space group $\mathrm{P} 2_{1} / \mathrm{c}$. The environment around the zinc (II) is square planar while the environment around the 7-fold sodium atom can be described as a severely distorted bipyramidal pentagon.

\section{Supplementary Materials}

CCDC-2011039 contains the supplementary crystallographic data for this paper. These data can be obtained free of charge via https://www.ccdc.cam.ac.uk/ structures/, or by e-mailing data_request@ccdc.cam.ac.uk, or by contacting The Cambridge Crystallographic Data Centre, 12 Union Road, Cambridge CB2 1EZ, UK; fax: +44 (0)1223336033.

\section{Conflicts of Interest}

The authors declare that they no competing interest.

\section{Acknowledgements}

The authors thank the FONDATION SONATEL for his financial support. http://fondationsonatel.sn/

\section{References}

[1] M. Nandy, D. Saha, C. Rizzoli, S. Shit, Trigonal dodecahedral sodium coordination in a trinuclear copper (II)-sodium complex incorporating a salen-type compartmental Schiff base. Zeitschrift Für Naturforschung B (2017), 72, 133-140.

[2] J.-P. Zhao, S.-D. Han, R. Zhao, Q. Yang, Z. Chang, X.-H. Bu, Tuning the structure and magnetism of heterometallic sodium (1+)-cobalt $(2+)$ formate coordination polymers by varying the metal ratio and solvents. Inorganic Chemistry (2013), 52, $2862-2869$.

[3] Z. Cai, D. Xiao, L. H. Do, Cooperative Heterobimetallic Catalysts in Coordination Insertion Polymerization. Inorganic Chemistry (2019), 39, 27-50.

[4] L. Wang, X. Pan, L. Yao, N. Tang, J. Wu, Ring-Opening
Polymerization of L-Lactides Catalyzed by ZincSodium/Lithium Heterobimetallic Complexes in the Presence of Water. European Journal of Inorganic Chemistry (2011), 2011, 632-636.

[5] R. Divya, V. T. Vineeth, B. R. Bijini, C. M. K. Nair, K. RajendraBabu, Growth and characterization of heterobimetallic copper-sodium complex of cyanuric acid: A novel photoluminescent material. Journal of Molecular Structure (2020), 1200, 127031.

[6] P. Bhowmik, S. Chatterjee, S. Chattopadhyay, Heterometallic inorganic-organic frameworks of sodium-nickel (vanen): Cation $-\pi$ interaction, trigonal dodecahedral $\mathrm{Na}+$ and unprecedented heptadentate coordination mode of vanen ${ }^{2-}$. Polyhedron (2013), 63, 214-221.

[7] P. P. Chakrabarty, D. Biswas, S. García-Granda, A. D. Jana, S Saha, Sodium ion assisted molecular self-assembly in a class of Schiff-base copper (II) complexes. Polyhedron (2012), 35, $108-115$.

[8] M. Andruh, Compartmental Schiff-base ligands-a rich library of tectons in designing magnetic and luminescent materials. Chemical Communications (2011), 47, 3025-3042.

[9] T. Gao, L.-L. Xu, Q. Zhang, G.-M. Li, P.-F. Yan, Salen-type heteronuclear $3 \mathrm{~d}-4 \mathrm{f}$ complexes engineering by anion PF6 with near-infrared (NIR) and luminescent properties. Inorganic Chemistry Communication (2012), 26, 60-63.

[10] J. Bian, $\{\mu-6, \quad 6$-Dimethoxy-2, 2'-[1, 2-phenylenebis (nitrilomethylidyne)] diphenolato $\}$ methanolcopper (II) sodium (I). Acta Crystallographica E (2008), 64, m625.

[11] X.-J. Ma, Aquachlorido $\{\mu-6, \quad 6$ '-diethoxy-2, 2'-[1, 2phenylenebis (nitrilomethylidyne)]diphenolato $\}$ copper (II) sodium (I) $N, \quad N$-dimethylformamide solvate. Acta Crystallographica E (2010), 66, m45.

[12] M. Usman, S. Tabassum, F. Arjmand, R. A. Khan, M. S. Ali, H. A. Al-Lohedan, A. Alsalme, M. A. Farah, K. M. Al-Anazi, M. Ahmad, $\mathrm{Cu}^{\mathrm{II}}-\mathrm{Na}^{\mathrm{I}}$ heteronuclear complex as anticancer entity against human breast cancer cell lines: DNA binding, cleavage, and Computational studies. Inorganica Chimica Acta (2018), 479, 229-239.

[13] P. Mukherjee, M. G. B. Drew, A. Figuerola, A. Ghosh, Incorporation of a sodium ion guest in the host of copper (II)Schiff-base complexes: Structural characterization and magnetic study. Polyhedron (2008), 27, 3343-3350.

[14] J. Lü, F. Li, D.-Q. Yuan, R. Cao, Assembly of two novel three-dimensional networks driven by Alkali metals with an irreversible structural conversion. Polyhedron (2007), 26, 2979-2986.

[15] P. Bhowmik, K. Harms, S. Chattopadhyay, Formation of polynuclear copper (II)-sodium (I) heterometallic complexes derived from salen-type Schiff bases. Polyhedron (2013), 49, 113-120.

[16] M. Das, S. Chatterjee, S. Chattopadhyay, Unique example of a trigonal dodecahedral $\mathrm{Na}^{+}$in a compartmental Schiff base $N$, $N^{\prime}$-(1, 2-Phenylene)-bis (3-methoxysalicylideneimine). Inorganic Chemistry Communications (2011), 14, 1337-1340.

[17] M. Sarr, E. I. Thiam, M. Gaye, A. H. Barry, N. Alvarez, J. Ellena, Co-crystal structure of a dinuclear $(\mathrm{Zn}-\mathrm{Y})$ and a trinuclear $(\mathrm{Zn}-\mathrm{Y}-\mathrm{Zn})$ complexes derived from a Schiff base ligand. European Journal of Chemistry (2018), 9, 67-73. 
[18] S. Thakurta, J. Chakraborty, G. Rosair, R. J. Butcher, S. Mitra, The interplay of $\mathrm{O}-\mathrm{H} \cdots \mathrm{O}$ hydrogen bonding in the generation of three new supramolecular complexes of $\mathrm{Cu}^{\mathrm{II}}, \mathrm{Ni}^{\mathrm{II}}$ and $\mathrm{Co}^{\mathrm{III}}$ : Syntheses, characterization and structural aspects. Inorganica Chimica Acta (2009), 362, 2828-2836.

[19] G. M. Sheldrick, it SHELXT - Integrated space-group and crystal-structure determination. Acta Crystallographica A (2015), 71, 3-8.

[20] G. M. Sheldrick, Crystal structure refinement with it SHELXL. Acta Crystallographica C (2015), 71, 3-8.

[21] L. J. Farrugia, it WinGX and it ORTEP for Windows: an update. Journal of Applied Crystallography (2012), 45, 849854.

[22] W. J. Geary, The use of conductivity measurements in organic solvents for the characterisation of coordination compounds. Coordination Chemistry Reviews (1971), 7, 81-122.

[23] Y.-M. Shen, W. Wang, $\{\mu-6,6$ '-Diethoxy-2, 2'-[ethane-1, 2diylbis (nitrilomethylidyne)] diphenolato $\}$ zinc (II) monohydrate. Acta Crystallographica E (2009), 65, m444.

[24] W.-K. Lo, W.-K. Wong, W.-Y. Wong, J. Guo, K.-T. Yeung, Y.-K. Cheng, X. Yang, R. A. Jones, Heterobimetallic Zn (II)Ln (III) phenylene-bridged Schiff base complexes, computational studies, and evidence for singlet energy transfer as the main pathway in the sensitization of near-infrared $\mathrm{Nd}^{3+}$ luminescence. Inorganic Chemistry (2006), 45, 9315-9325.

[25] P. Haba, M. M. Sow, M. Sarr, I. E. Thiam, M. Diaw, M. L.
Gaye, Syntheses, Characterization and X-ray Crystal Structure of Polymeric Heteronuclear Oxo-bridged Fe/Na Assembled with Salen-type Schiff Base and Dicyanamide. Science Journal of Chemistry (2020), 8, 20-27.

[26] C. R. Groom, I. J. Bruno, M. P. Lightfoot, S. C. Ward, The Cambridge Structural Database. Acta Crystallographica B (2016), 72, 171-179.

[27] J. Andrez, V. Guidal, R. Scopelliti, J. Pécaut, S. Gambarelli, M. Mazzanti, Ligand and Metal Based Multielectron Redox Chemistry of Cobalt Supported by Tetradentate Schiff Bases. Journal of the American Chemical Society (2017), 139, 86288638 .

[28] A. Biswas, S. Mondal, S. Mohanta, Syntheses, characterizations, and crystal structures of $3 \mathrm{~d}-\mathrm{s} / \mathrm{d} 10$ metal complexes derived from two compartmental Schiff base ligands. Journal of Coordination Chemistry (2013), 66, 152170 .

[29] X. Feng, K. Y. Wu, S. Y. Xie, R. Li, L. Wang, A heterometallic polymer based on bis-salicylidene Schiff base ligand, synthesis, electronic chemistry, and antibacterial property. Inorganic and Nano-Metal Chemistry (2017), 47, $1134-1140$.

[30] T. M. Seck, M. Diop, D. Diouf, O. Diouf, A. H. Barry, M. Gaye, Synthesis, spectroscopic studies and crystal structure determination of a tetranuclear $\mathrm{Zn}$ (II) [2x2] square grid structure of 1, 5-bis (1-(pyridin-2-yl) ethylidene) carbonohydrazide, IOSJR Journal of Applied Chemistry (2018), 11, 06-14. 